\title{
Terrestrial Laser Scanner techniques in the assessment of tsunami impact on the Maddalena peninsula (south-eastern Sicily, Italy)
}

\author{
G. Scicchitano ${ }^{1,5}$, C. Pignatelli ${ }^{2,3}$, C. R. Spampinato ${ }^{1}$, A. Piscitelli ${ }^{4}$, M. Milella ${ }^{4}$, C. Monaco ${ }^{1}$, and G. Mastronuzzi ${ }^{2,3}$ \\ ${ }^{1}$ Dipartimento di Scienze Geologiche, Università di Catania, Corso Italia, 55, 95129 Catania, Italy \\ ${ }^{2}$ Dipartimento di Scienze della Terra e Geoambientali, Università degli Studi 'Aldo Moro' di Bari, Via E.Orabona, 4, 70125, Bari, Italy \\ ${ }^{3}$ LAGATTA LAboratorio Gis geoAmbientale e di Telerilevamento-Taranto, II Facoltà di Scienze Matematiche, Fisiche e Naturali, \\ Università degli Studi “Aldo Moro”, Via A. De Gasperi, 74123 Taranto, Italy \\ ${ }^{4}$ Environmental Surveys s.r.l., Via Della Croce 156, 74100 Taranto, Italy \\ ${ }^{5}$ Studio Geologi Associati T.S.T. Via Galliano, 157, 95045, Misterbianco, Catania, Italy
}

(Received November 24, 2010; Revised November 5, 2011; Accepted November 7, 2011; Online published October 24, 2012)

\begin{abstract}
The coastline of the Maddalena peninsula (south-eastern Sicily, Italy) is characterised by the occurrence of a boulder field associated to an extended soil stripping area and by a gravel/sandy berm. The accumulation of the boulders has been mostly correlated to the impact of the December 28, 1908 tsunami wave. The use of Terrestrial Laser Scanner survey techniques, associated to Differential Global Position System determinations, permits to obtain new data for the assessment of tsunami impact on this coastal area. The computing of the surveyed data using the most recent equations is a useful tool in order to estimate the theoretic inundation limit and to reconstruct its variability in function of the boulders size and of the coastal topography. Moreover, the entire new data set allows to confirm that the hypothesis of the tsunami impact is the most reasonable to explain the occurrence of boulders weighing up to 50 tons on the Maddalena peninsula.
\end{abstract}

Key words: Tsunami, hydrodynamic model, Laser Scanner Techniques, Sicily, Italy.

\section{Introduction}

One of the most impressive evidence of extreme wave impact on the rocky coasts is represented by the presence of mega-boulders, sparse or accumulated in field or berms (Mastronuzzi and Sansò, 2000, 2004; Williams and Hall, 2004; Hall et al., 2006, 2008; Scheffers and Scheffers, 2006; Mastronuzzi et al., 2007; Scicchitano et al., 2007; Goto et al., 2009a, b, 2010a). The post-event surveys performed after the impact of the Indian Ocean Tsunami (IOT), occurred on December 26, 2004, have permitted to recognise morphological/sedimentological effects of its impact and, in the same time, to extend all obtained results on coastal sectors where similar evidences were recognised (e.g. Szczuciski et al., 2005; Kelletat et al., 2006, 2007; Lavigne et al., 2006; Richmond et al., 2006; Paris et al., 2007, 2009, 2010; Srinivasalu et al., 2007; Umitsu et al., 2007). In particular, it has been demonstrated that frequently the wave flow has been able to detach and scatter inland boulders of significant size and weight (Goto et al., 2009a, b). Notwithstanding the immense number of data derived by the surveys performed all along the coast hit by the IOT, the debate about the correlation of these landforms/sediments with the extreme event responsible of their genesis/deposit is still open. In fact, since the absence of eyewitness, at present, no undisputable signatures allow to discriminate between the boulders accumulated by a sea

Copyright (C) The Society of Geomagnetism and Earth, Planetary and Space Sciences (SGEPSS); The Seismological Society of Japan; The Volcanological Society of Japan; The Geodetic Society of Japan; The Japanese Society for Planetary Sciences; TERRAPUB.

doi:10.5047/eps.2011.11.009 storm from those accumulated by tsunami. The reply to this scientific question was the increase of the number of papers examining the nature of these landforms/sediments, focusing their attention on the wave forces necessary to detach, transport and deposit boulders of different size and weight (e.g. Nott, 1997, 2003; Noormets et al., 2004; Scheffers and Kelletat, 2005; Kelletat et al., 2006, 2007; Mastronuzzi et al., 2006; Scheffers, 2006, 2008; Goto et al., 2007, 2010b; Scicchitano et al., 2007; Imamura et al., 2008; Kelletat, 2008; Benner et al., 2010; Goff et al., 2010; Regnauld et al., 2010).

The occurrence of boulders eradicated from the infralittoral/adlittoral zones is considered evidence of the past impact of extreme waves. Starting from the presence of boulders and from their size, some authors consider really possible to evaluate the features of the impacting waves. An important degree of uncertainty regards the methodology aiming to the definition of the origin of the wave responsible for their deposition. In the boulder accumulation process, is the impacting wave height more important compared to the wave length and to the wave period? Different theories have been proposed in the recent time, but the final reply is still far away (Nott, 2003; Goto et al., 2007, 2009b, 2010b; Hansom et al., 2008; Imamura et al., 2008; Pignatelli et al., 2009; Barbano et al., 2010). The more easy reply is that if a wave can be described by height, length and period, the best way to evaluate its impact on a rocky coast should consider these parameters all together.

The aim of this paper is to estimate the inland penetration limit of tsunami waves responsible for boulder deposition applying the Pignatelli et al. (2009) method. In particular, 


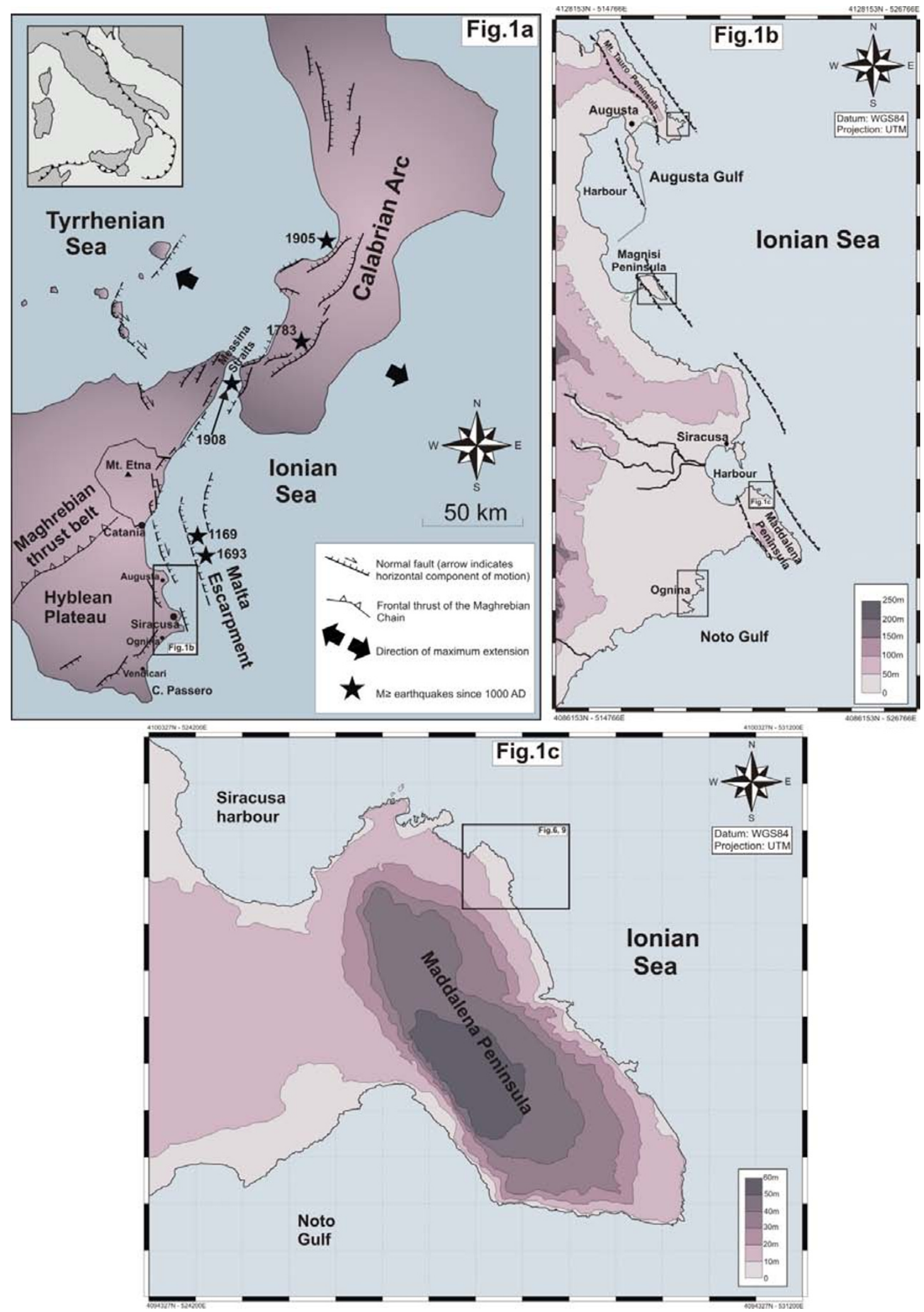

Fig. 1. (a) Tectonic sketch map of south-eastern Sicily. Inset shows the seismotectonic features of the Siculo-Calabrian rift zone (Monaco and Tortorici, 2000) and its location in the central Mediterranean area (line with triangles indicates the frontal thrust of the orogenic belt). (b) Geographical position of the sites studied by Scicchitano et al. (2007, 2010) along the Ionian coast of southeastern Sicily, in the Augusta-Siracusa area (see Fig. 1(a) for location). (c) The studied area (box) on the north-eastern corner of the Maddalena peninsula (see Fig. 1(b) for location).

Terrestrial Laser Scanner (TLS) and Differential Global Position System (DGPS) techniques were used to survey some boulders accumulated on the Maddalena peninsula (Fig. 1), along the south-eastern coasts of Sicily (Italy), whose ac- cumulation has been ascribed to the impact of three different and famous tsunamis occurred during the 1169, 1693 and 1908 seismic events (Scicchitano et al., 2007). The use of the TLS techniques allows an accurate evaluation of the 
boulders size and weight whose accuracy is fundamental in order to test the reliability of the known hydrodynamic equations.

\section{Geological and Geomorphological Setting}

South-eastern Sicily is one of the most seismically active areas of the central Mediterranean (Fig. 1(a)). It is characterized by thick Mesozoic to Quaternary carbonate sequences and volcanics forming the emerged foreland of the Siculo-Maghrebian thrust belt (Grasso and Lentini, 1982). This area, mostly constituted by the Hyblean Plateau, is located on the footwall of a large normal fault system which since the Middle Pleistocene has reactivated the Malta Escarpment (Hirn et al., 1997; Bianca et al., 1999), a Mesozoic boundary separating the continental domain from the oceanic crust of the Ionian basin (Scandone et al., 1981; Sartori et al., 1991; Argnani and Bonazzi, 2005). Since the Middle Pleistocene, active faulting has contributed to continuous extensional deformation from eastern Sicily to western Calabria (Siculo-Calabrian Rift Zone, see inset in Fig. 1(a); Monaco and Tortorici, 2000; Jacques et al., 2001). In eastern Sicily the SSW-NNE striking normal faults are mostly located offshore and control the Ionian coast from Messina to the eastern lower slope of Mt. Etna, joining southwards to the NNW-SSE trending system of the Malta Escarpment. This area is marked by a high level of crustal seismicity producing earthquakes with MCS (Mercalli-Cancani-Sieberg) intensities of up to XI-XII and $M \sim 7$, such as the 1169, 1693 and 1908 events (Postpischl, 1985; Boschi et al., 1995). Several earthquake-generated tsunamis struck the Ionian coast of south-eastern Sicily in historical times (AD 1169, 1329, 1693, 1818, 1908, 1990; Tinti et al., 2004, 2007; Scicchitano et al., 2007; Smedile et al., 2011). According to most of published geological data and numerical modelling, the seismogenic source of these events should be located in the Messina Straits and in the Ionian offshore (the Malta Escarpment) between Catania and Siracusa (Baratta, 1910; Barbano and Cosentino, 1981; Carbone et al., 1982; Barbano, 1985; Lombardo, 1985; Postpischl, 1985; Ghisetti, 1992; Valensise and Pantosti, 1992; Piatanesi and Tinti, 1998; Bianca et al., 1999; Azzaro and Barbano, 2000; Monaco and Tortorici, 2000; Tinti and Armigliato, 2003). However it is important to consider that other source such as submarine landslides or volcanic eruption, could be responsible of the generation of tsunamis that struck the Ionian coast of south-eastern Sicily (Mastronuzzi, 2010).

Geomorphological evidences of extreme waves impact are present all along the coast of south-eastern Sicily between the town of Augusta and Capo Passero (Fig. 1(a)). Scicchitano et al. (2007) described boulder deposits related to tsunami and storm generated waves between Augusta and Siracusa (Fig. 1(b)). Hydrodynamic estimations and radiocarbon age determinations suggested that three distinct tsunami events $(1169,1693,1908)$ were responsible for the deposition of the biggest isolated boulders and boulder fields. Along the coast of Vendicari, $40 \mathrm{~km}$ south of Siracusa (Fig. 1(a)), Barbano et al. (2010) discovered a boulder field and isolated boulders related to different tsunami events. Moreover, tsunami impact deposits related to the 1693 event and other tsunami and storm deposits were found preserved within a ria-type rocky coastal setting at the bottom of the channel harbour of Ognina, $20 \mathrm{~km}$ south of Siracusa (Scicchitano et al., 2010). Finally, De Martini et al. (2010) and Smedile et al. (2011) evidenced the occurrence of out of place coarse layers ascribed to distinct tsunami waves that invaded lagoon and marine environments near Augusta.

The boulder deposit described in this paper has been found near Siracusa, south-east Sicily (Fig. 1(b)), along the north-eastern corner of the Maddalena peninsula that bounds to the south the large natural harbour of the town.

\section{Boulder Setting}

The Maddalena peninsula (Fig. 1(c)) is a calcareous semi-horst gently tilted to the ENE, formed by Miocene limestones that along the coast are unconformably covered by Pleistocene calcarenites. Most boulders are scattered at a distance of up to $70 \mathrm{~m}$ from the coastline (Scicchitano et al., 2007) on a large Pleistocene wave-cut platform located 5-10 $\mathrm{m}$ above sea level (a.s.1.), gently sloping towards the sea and bordered by up to $5 \mathrm{~m}$ high cliffs. The near-shore sea bottom topography is irregular, being characterized by two steps at $-6 /-10 \mathrm{~m}$ and at $-10 /-32 \mathrm{~m}$. The blocks are mostly arranged in isolated elements (Figs. 2(a, b)) and have also been found on a flat anthropogenic platform at 1$2 \mathrm{~m}$ a.s.l. inside an ancient Greek quarry located along the coast and nowadays partially submerged (Scicchitano et al., 2008) (Figs. 2(c, d)). Locally, small groups composed of stacked elements occur. It's worth to note that the boulders are preferentially accumulated on sectors of promontories exposed towards north-east (Fig. 1(c)), where the offshore source areas of earthquakes are located (active faults in the Messina Straits and at the foot of the Malta Escarpment, see Fig. 1(a)).

The studied area is characterized by the occurrence of a well developed berm (Fig. 3(a)) located at a distance ranging between $80 \mathrm{~m}$ and $90 \mathrm{~m}$ from the coastline (Marziano, 2004). The berm is composed by coarse sand and pebbles organized into a cross laminated stratification lying on a paleo-soil (Fig. 3(b)). Various shells and shell fragments were recognized in the berm and several pottery and human manufactory were distinguished too (Fig. 3(c)). The occurrence of several boulders, up to 1 ton in weight, on the berm (Fig. 3(d)) was interpreted by Marziano (2004) as evidence of its deposition by extreme waves.

In order to estimate the inland penetration limit of tsunami waves responsible for boulder deposition, our study has been focused on the three biggest boulders described in the area by Scicchitano et al. (2007), that are B3, B4 and B13 (Fig. 2) whose features indicate a joint bounded scenario JBS. TLS and DGPS techniques were used to survey both boulders and berm.

\section{Hydrodynamic Equations}

Nott (1997) proposed hydrodynamic equations in order to evaluate the height of tsunami or of severe storm waves able to detach and move boulders. These equations take into account boulder dimensions ( $a$-axis $=$ major axis, $b$-axis $=$ medium axis, $c$-axis = minor axis), boulder shape and den- 

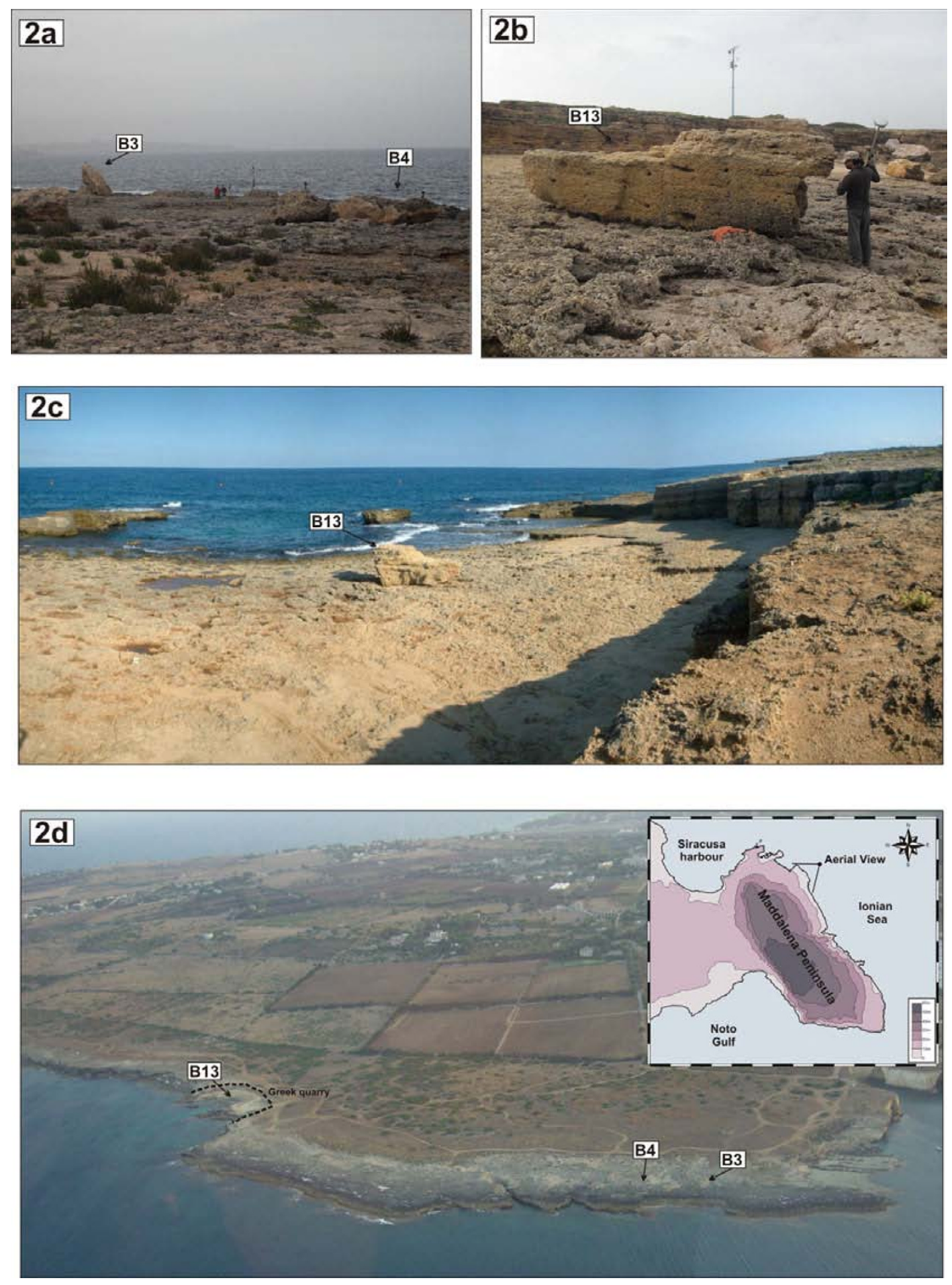

Fig. 2. (a) Boulders B3 and B4 along the coast of Maddalena peninsula. (b) Boulder B13 located inside an ancient Greek quarry. (c) Panoramic view of the ancient Greek quarry located on the north-eastern corner of the Maddalena peninsula. (d) Aerial view of the studied area (photograph supplied by Marine Protected Area of Plemmirio, Siracusa). The arrows indicate the analyzed boulders.

sity of rock (bulk density). Nott (2003) improved these equations introducing the pre-transport settings and, to be more precise, the determination of the main morphological features of the deposited boulders: the position prior to the tsunami impact, the size, the shape and rock density. Indeed, the reconstruction of the position prior to the tsunami impact could be extremely important in the prediction of the possible future scenarios. Three different scenarios were hypothesized: the first one considers a boul- der placed on a cliff edge (joint bounded scenario JBS); in the second one, the boulder is taken up and placed below sea level (submerged scenario SMS); in the last one, the boulder is detached and placed inland (sub-aerial scenario SAS). Many authors used Nott's equations to determine if sea storm or tsunami were responsible for boulder displacement (e.g. Scheffers, 2002, 2004; Mastronuzzi and Sansò, 2004; Mastronuzzi et al., 2007; Scicchitano et al., 2007; Maouche et al., 2009); some of these studies have 

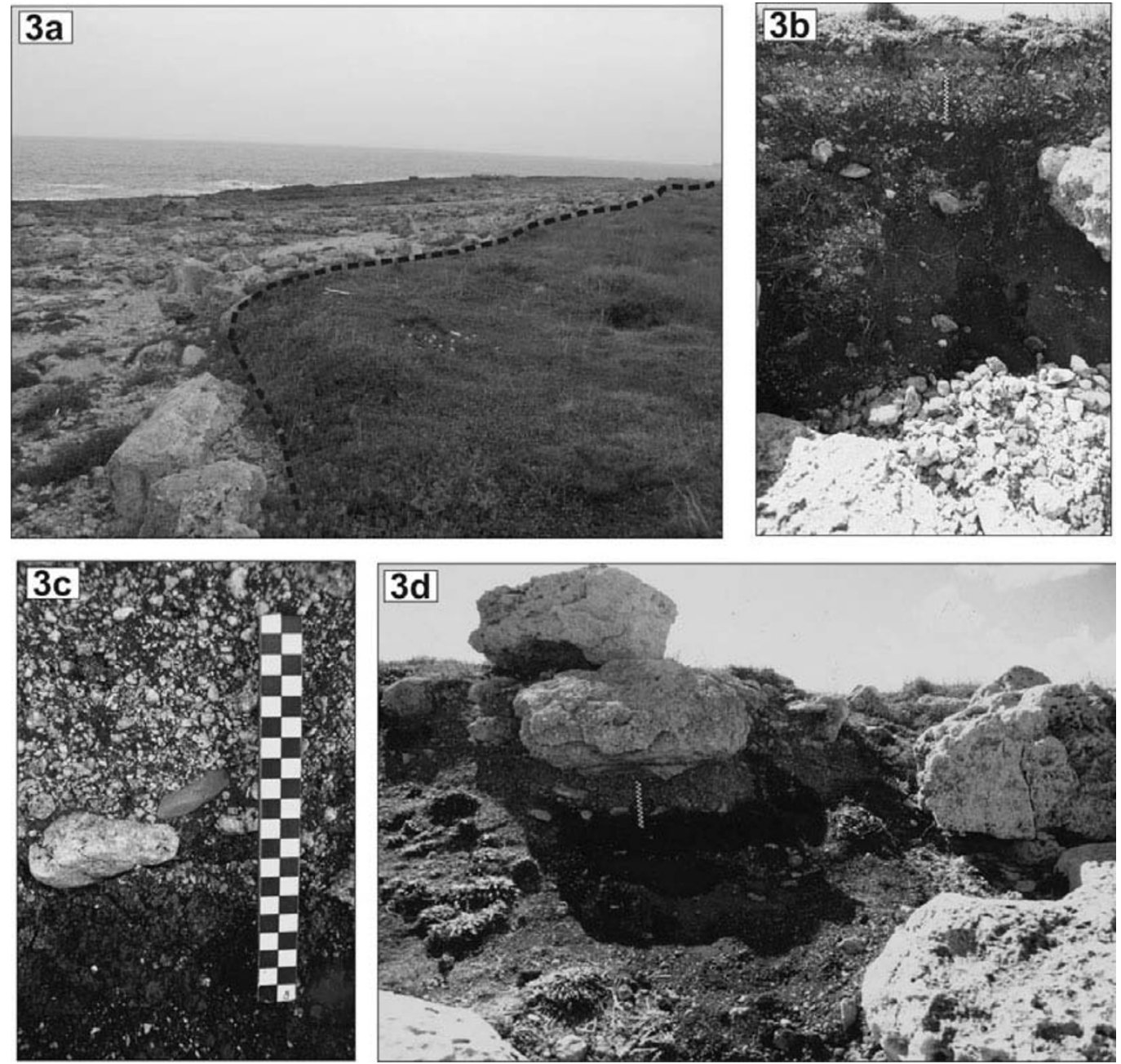

Fig. 3. (a) View of the berm located in the north-eastern corner of the Maddalena peninsula. (b) Natural section of the berm showing coarse sands and pebbles lying on a paleo-soil (see Marziano, 2004). (c) Human manufactory found in the berm deposit; (d) Boulders overlying the berm deposit.

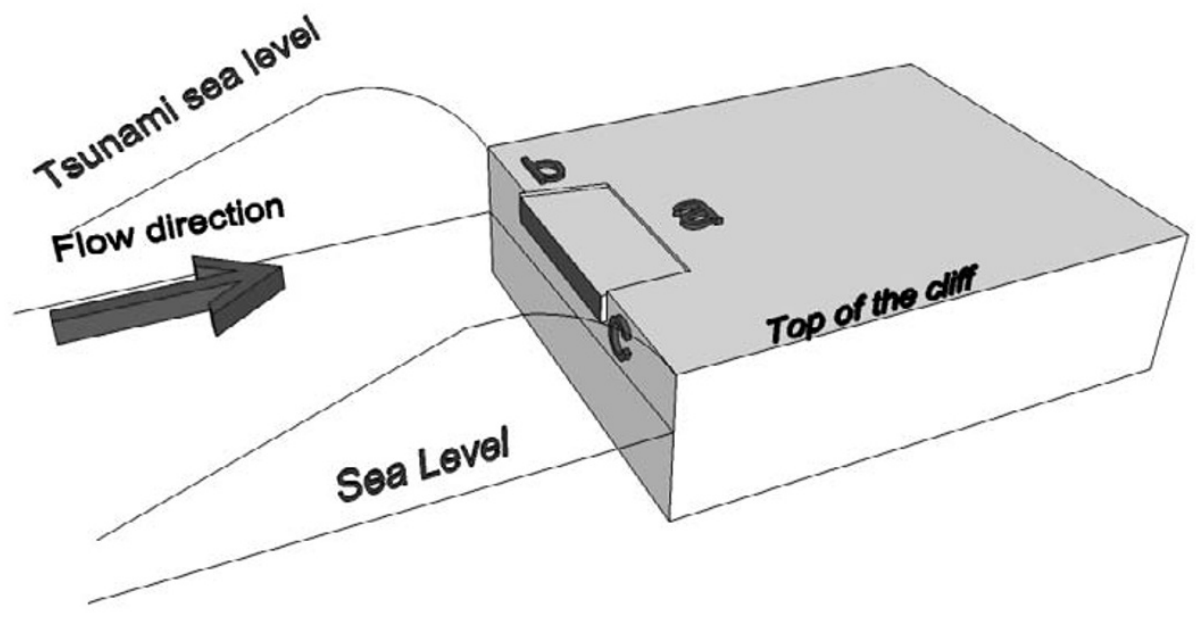

Fig. 4. 3D representation of the tsunami impact on a rocky coast. The small parallelepiped represents a boulder in joint bounded conditions. $a, b, c$ : main axes of the boulder. The $a \times c$ red surface is directly exposed to wave.

permit to deduce that storm and tsunami heights calculated by Nott's equations appear overestimated (e.g. Scheffers, 2002, 2004; Paris et al., 2009; Goto et al., 2010b; Bourgeois and MacInnes, 2010). Moreover, starting from the study of boulder accumulated by past tsunami impacting the Apulia coasts (southern Italy), Pignatelli et al. (2009) introduced new equations that optimize the Nott's theory. According to Pignatelli et al. (2009), boulders come from the emergedor immediately submerged-part of the cliff in JBS condition, drawing a scenario that is very similar to the geomor- 
phological situation described by Noormets et al. (2002, 2004); the boulder is placed still in the outcropping rock but loose along joints at all sides. In this condition the $a \times c$ face of the boulder-c-axis indicates the thickness-is directly exposed to wave impact (Fig. 4). The Pignatelli et al. (2009) hydrodynamic equation is:

$$
H_{\mathrm{T}}=\left[0.5 \cdot c \cdot\left(\rho_{\mathrm{b}}-\rho_{\mathrm{w}}\right) / \rho_{\mathrm{w}}\right] / C_{\mathrm{L}}
$$

where $H_{\mathrm{T}}$ is the tsunami height at breaking point, $c$ axis is the boulder height (thickness), $\rho_{\mathrm{b}}$ is the density of boulder, $\rho_{\mathrm{w}}$ is the density of water $=1.02 \mathrm{~g} / \mathrm{ml} ; C_{\mathrm{L}}$ is the coefficient of lift $=0.178$ (see Bryant, 2001). In the scenario hypothesized by Pignatelli et al. (2009) it is possible to calculate the tsunami height at the top of the cliff; the wave heights used to simulate the tsunami flooding are assessed in relation to the boulder scattered inland. If a boulder is detached from cliff edge (joint bounded scenario), the height of the water column flooding can be obtained from this relation:

$$
H_{\mathrm{FL}}=H_{\mathrm{T}}-\text { Altitude of the cliff. }
$$

In fact, at the edge of the cliff, where the boulders initially were placed, the tsunami height must be not smaller than the minimum wave able to move the biggest boulder.

Hills and Mader (1997) provided an empirical formula that permits to calculate the inland flooding limit $X_{\mathrm{FL}}$ of an impacting tsunami:

$$
X_{\mathrm{FL}}=\left(H_{\mathrm{FL}}\right)^{1.33} n^{-2} k
$$

where: $H_{\mathrm{FL}}$ is tsunami height at coastline; $n$ is Manning's number (see below), $k=0.06$ is a constant for many tsunamis (see Bryant, 2001). This formula provides good estimation for coasts characterised by overland flat profile. In the reality, often the coastal sectors show sloping overland profile very complex, conditioned by the local lithostructural features. Starting from the cited formula, considering boulder accumulated by tsunami at a distance $D$ from the coastline, a factor $\cos \alpha$-where $\alpha$ represents the mean sloping-has been introduced (Pignatelli et al., 2009); this permit to take into account the coastal overland profile:

$$
X_{\mathrm{FL}}=D+\left(H_{\mathrm{FL}}\right)^{1.33} n^{-2} k \cos \alpha .
$$

The Manning number is a coefficient expression of the micro-topography and sinuosity of the surface; it represents the hydraulic roughness of the terrain propriety that causes resistance to the water flow by creating a retarding force (Chow, 1973). Various authors have estimated Manning coefficient for distinct terrain typology (Arcement and Schneider, 1989) but the obtained values are often approximated since their absolute value did not derive by strictly quantitative surveys. As consequence, the use of the Hills and Mader (1997) equation adopting distinct Manning coefficient is not always rigorous. Moreover, an important aspect that should not be neglected is the roughness variability over time. In fact, the Manning coefficient is not constant with time in the same place due to weed and/or urban growth (Asal, 2003). As a consequence, in a coastal sector it is possible to obtain an evaluation of the present roughness useful for the elaboration of a near-future scenario, but that is not representative of a past tsunami impact (i.e. Pignatelli et al., 2010).

\section{Material and Methods}

The assessment of the inland penetration limit of tsunami waves using the Pignatelli et al. (2009) method implies the possibility of accurately measuring dimension, geometry and position of the main boulders recognised along studied coastal areas. Terrestrial Laser Scanner (TLS) techniques were used to perform accurate $3 \mathrm{D}$ reconstruction of the three biggest boulders located along the coastline of the Maddalena peninsula, whose accumulations have been ascribed to the impact of different large tsunami (Scicchitano et al., 2007).

Recent TLS technology is based on the reflectorless acquisition of a point cloud of the topography using the timeof-flight distance measurement of laser pulse (Slob and Hack, 2004). The scanner consists of a laser beam generator, a mirror rotating on its horizontal axis and forming a $45^{\circ}$ degree angle with the beam direction and a servomotor which makes the instrument rotate around its vertical axis. This setting gives to the scanner a field view of $360^{\circ} \times 270^{\circ}$. The monochromatic and nearly parallel laser pulse is sent out in a precisely known direction. The scanner then records the back-scattered pulse. The time-of-flight of the signal is then converted into the distance between the scanner and the object; these two values are used to calculate Cartesian coordinates with reference to the centre of the scanner.

On March 2009 and April 2010 measurements have been performed on the cited boulders surveyed in the Maddalena peninsula (B3, B4, B13) using a Leica Scanstation 2 (Fig. 7(a)); the measurements have been finalised to verify the occurrence of possible movements after the impact of the very strong storms occurred in the span of time ranging from 2008 to 2010. The instrument captures up to a maximum of 50,000 points/sec over a maximum range between 200 and $300 \mathrm{~m}$, depending on the reflectivity of the scanned object. A single scan representing a simple point of view is not enough to realize an accurate $3 \mathrm{D}$ reconstruction of the boulders, but the TLS kit is supplied with circular/rectangular targets characterised by a very reflective surface (Fig. 5(a)); their position can be acquired for a simple take and distinction to the beam of the scanner. Therefore, to obtain a complete $3 \mathrm{D}$ model, it is necessary to overlap numerous scans performed from different point of views using selected targets as reference points. The TLS complete datasets acquired were treated and analysed using the HDS Cyclone software (Leica Geosystems, 2004). All the raw scans were manually cleaned to remove any outliers such as vegetation or anthropogenic features. TLS surveys generated cloud points that permitted to reconstruct a 3D model in order to define shapes and volumes of the boulders selected in the studied areas; using a reverse engineering software, the 3D cloud points were converted to a TIN (triangulated irregular network) model which consists of closed surface. Moreover, the model showed holes and gaps due both to scan and to surface interpolations. The fill holes operation closes the polygonal structures and makes the layout continuous. The complete reconstruction of lacking parts, also at the bottom, was supported by the using of pictures and allowed to define a more realistic shape of the measured boulders. 

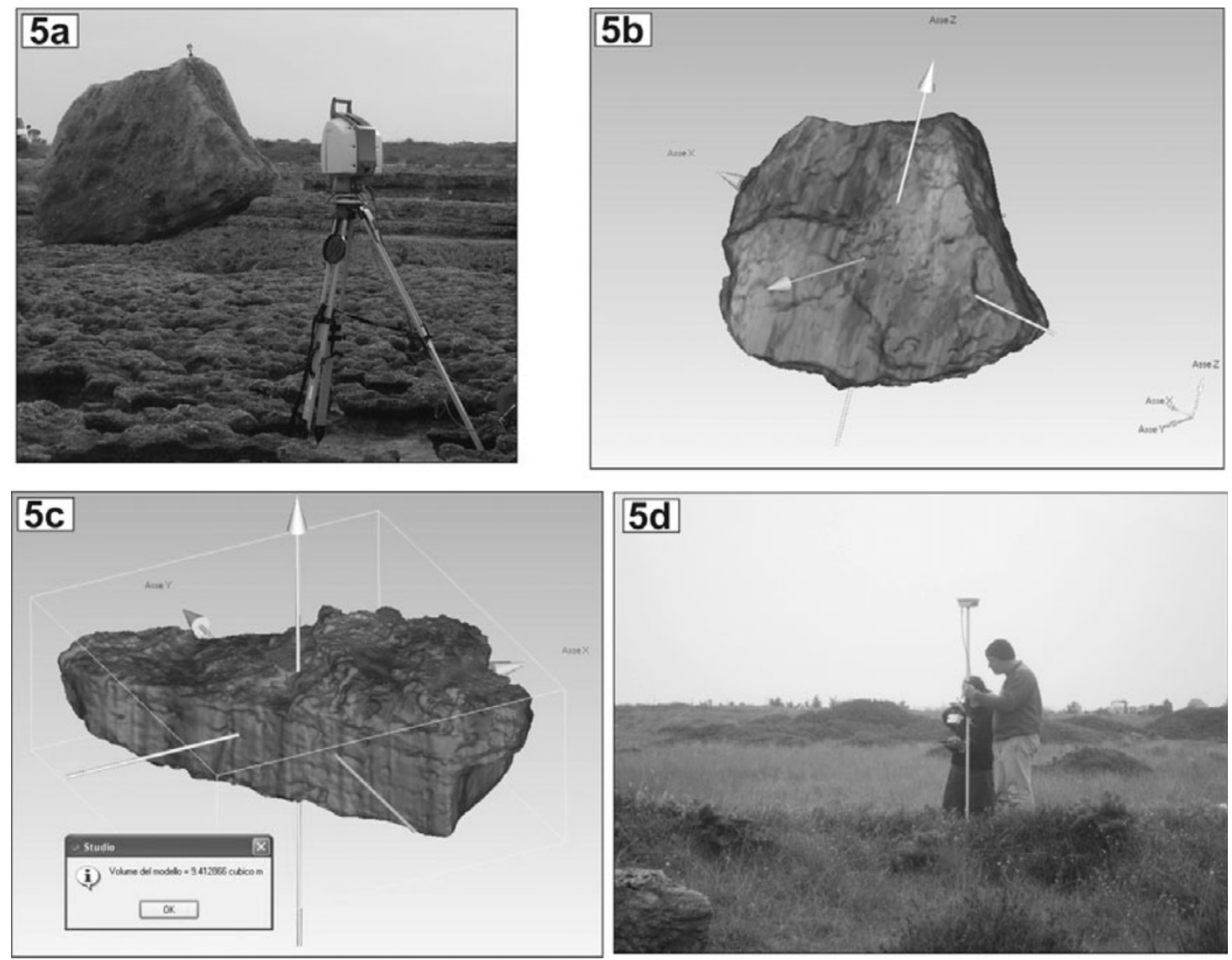

Fig. 5. (a) The Scan Station 2 used to perform TLS survey at Maddalena Penisula; (b) Boulder B3 reconstruction obtained applying software interpolation to TLS points cloud; (c) The boulder B3 volume calculated with reverse engineering software tool; (d) DGPS instrument operating in field.

Table 1. Mean parameters for the three boulders studied in the Maddalena peninsula: axis dimensions $(a, b, c)$, Volume $(V)$, Density $\left(\rho_{\mathrm{b}}\right),($ Weight $(W)$, Distance from the coast line $(D)$, Tsunami wave height $\left(H_{\mathrm{t}}\right)$. In bracket are reported values estimated by Scicchitano et al. (2007) for the same boulders.

\begin{tabular}{|c|c|c|c|c|c|c|c|c|}
\hline Boulder & $a(\mathrm{~m})$ & $b(\mathrm{~m})$ & $c(\mathrm{~m})$ & $V\left(\mathrm{~m}^{3}\right)$ & $\rho_{\mathrm{b}}\left(\right.$ ton $\left./ \mathrm{m}^{3}\right)$ & Weight $($ ton $)$ & $D(\mathrm{~m})$ & $H_{\mathrm{t}}(\mathrm{m})$ \\
\hline B3 & $5.76-(8)$ & $4.95-(5)$ & $1.4-(0.7)$ & $21.35-(28)$ & $2.33-(2.28)$ & $49.746-(59.64)$ & $33-(28)$ & $5.051-(6.82)$ \\
B4 & $3.951-(4.9)$ & $3.596-(3.5)$ & $1.088-(1)$ & $9.368-(17.5)$ & $2.08-(2.28)$ & $19.480-(39.10)$ & $33-(35)$ & $3.174-(3.04)$ \\
B13 & $4.746-(5)$ & $2.386-(3.2)$ & $1.343-(1)$ & $9.396-(16)$ & $1.98-(2.28)$ & $18.643-(36.48)$ & $12-(18)$ & $3.566-(2.63)$ \\
\hline
\end{tabular}

The 3D model reconstruction of the boulders allows to gauge the $a, b, c$ axes more accurately than their measures obtained by classical field survey. In particular, to assess the mean value of each axis, several measures can be catch over the whole boulder. Moreover, the 3D model provides the correct volume which is essential to estimate the boulder weight, knowing the rock density (Figs. 5(b, c); Table 1). Finally, in order to apply the Pignatelli et al. (2009) method for calculating the minimum wave height of tsunami or sea storm able to move the boulders and the inland penetration limit, it is important to know in detail the coastal topography especially in the coastal sector where the largest boulders are recognised. Highly accurate plano-altimetric surveys (Fig. 5(d)) were carried out with a Differential Global Position System (DGPS) in Real Time Kinematic (RTK) mode. This allowed to obtain the altitude of the cliff along the considered shoreline, the slope, the position of each studied boulder and the inner limit of a sandy/vegetated berm recognised along the studied area.

\section{Data Analysis}

We tested the Pignatelli et al. (2009) method, by applying it to the boulder field at the Maddalena peninsula, with the aim of calculating the max inland penetration limit of a tsunami wave that is able to transport boulders. We selected the three biggest boulders occurring in the area whose features indicate an original joint bounded partially submerged pre transport setting: for each boulder we performed accurate $3 \mathrm{D}$ reconstruction using TLS method for measuring the $a, b, c$ axes. Several samples were collected from the selected boulders to determinate an accurate average value of $\rho_{\mathrm{b}}$. Using the formula (1) we calculated the tsunami height at breaking point $H_{\mathrm{T}}$ for the three boulders selected (Table 1). $H_{\mathrm{T}}$ values so obtained were subsequently introduced into Eqs. (2) and (3) to obtain the maximum inland penetration limit $D$ of a tsunami wave that is able to transport the analysed boulders. The $D$ value has been estimated for each boulder starting from the 3D reconstruction obtained by using the TLS survey. The parameters $n$ 


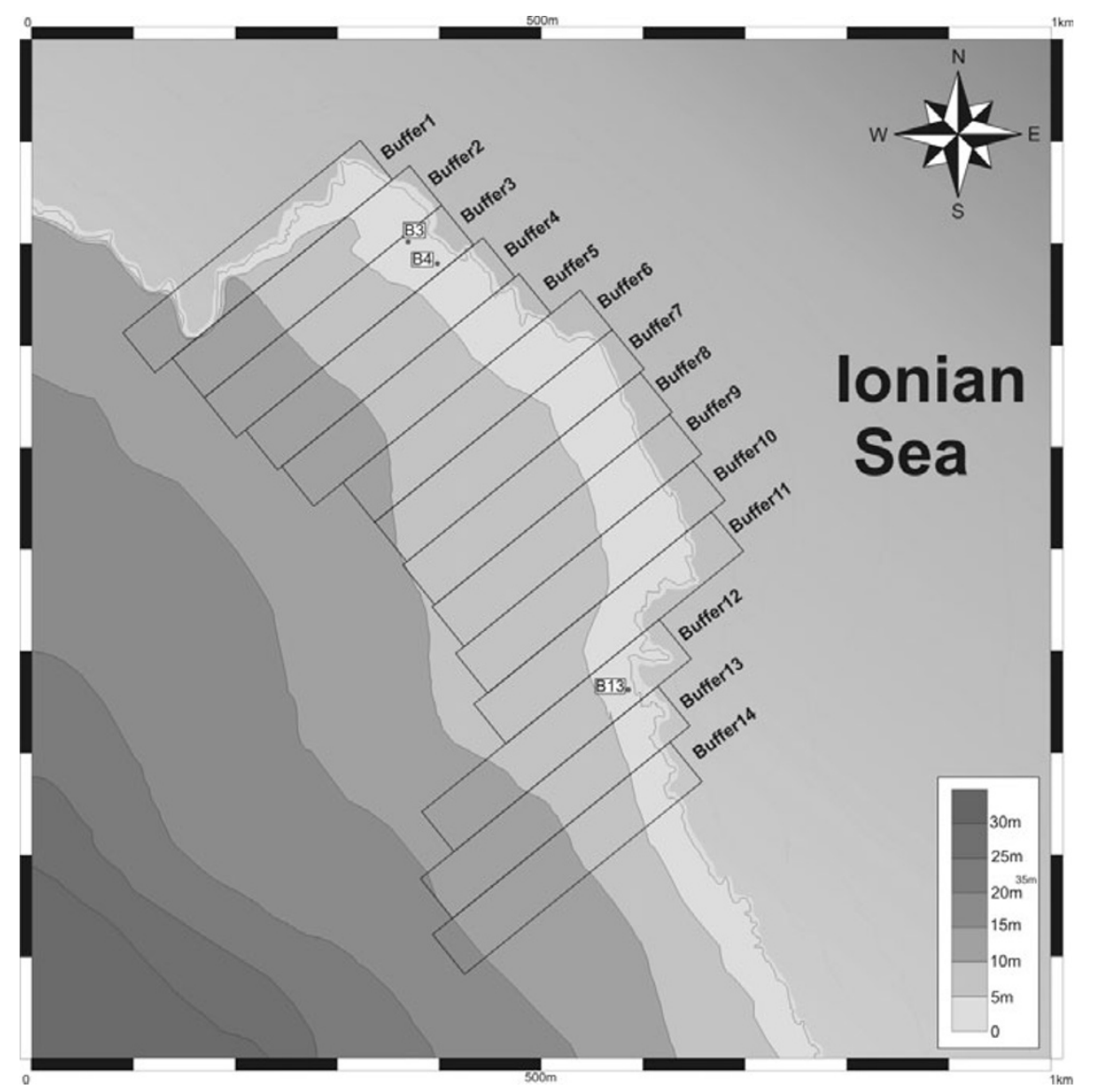

Fig. 6. Sketch map showing the studied area divided into 14 buffer $(300 \times 50 \mathrm{~m})$ (see Fig. 1(c) for location).
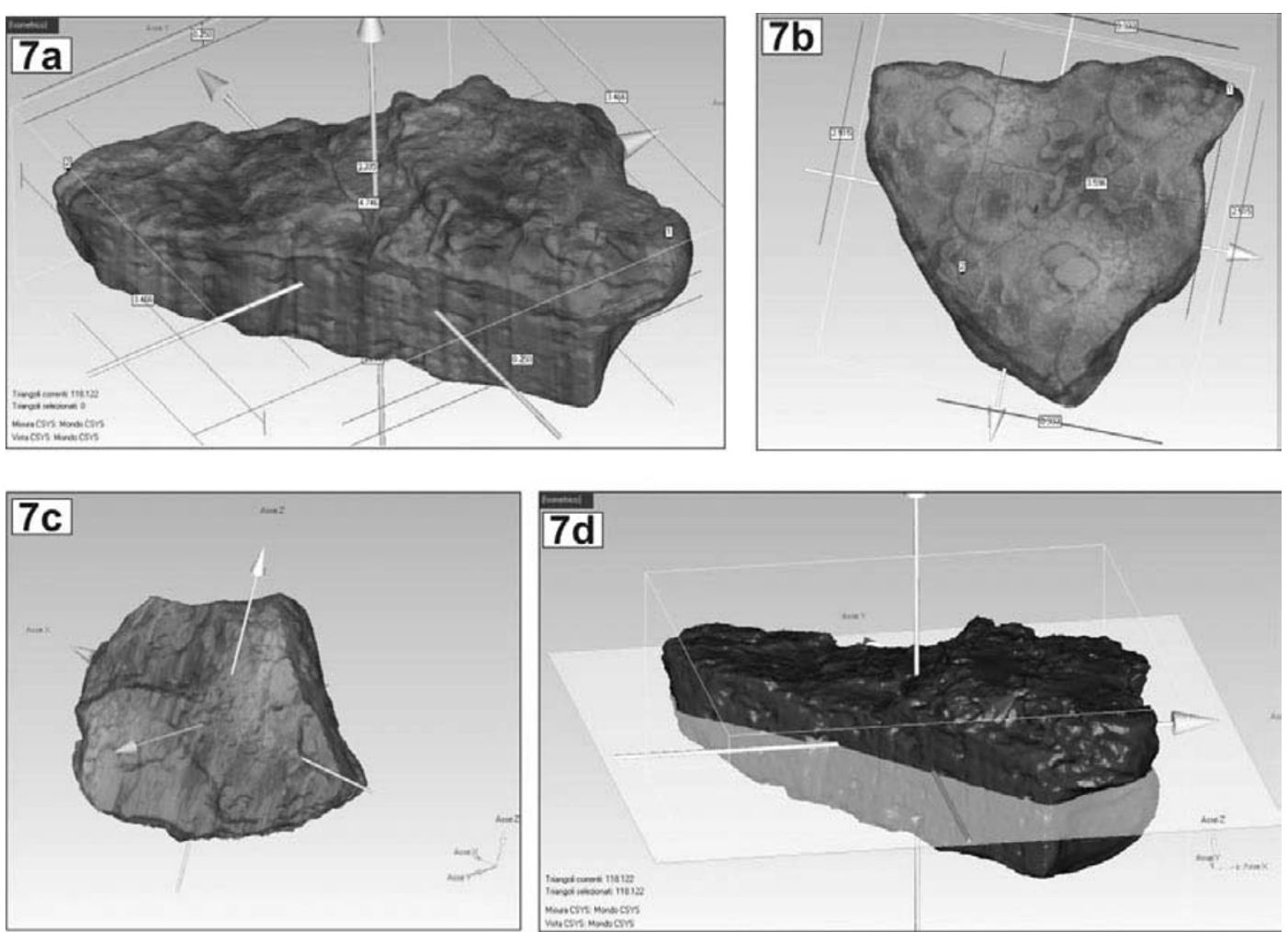

Fig. 7. 3D model reconstructions of boulder B13 (a), B4 (b) and B3 (c). (d) Elaboration of the 3D model reconstruction of boulder B13. 
Table 2. Values of height of the cliff $\left(h_{\mathrm{c}}\right)$, mean slope $(\alpha)$ and roughness $(n)$ for each one of the 14 buffer in which the studied area has been divided (see Fig. 8).

\begin{tabular}{|c|c|c|c|}
\hline Buffer number & $h_{\mathrm{c}}(\mathrm{m})$ & $\alpha\left(^{\circ}\right)$ & Manning number \\
\hline 1 & 1.5 & 4 & 0.042 \\
2 & 1.8 & 4 & 0.041 \\
3 & 1.7 & 4 & 0.041 \\
4 & 1.8 & 4 & 0.041 \\
5 & 1.7 & 3.8 & 0.042 \\
6 & 1.6 & 2.7 & 0.041 \\
7 & 1.8 & 2.6 & 0.041 \\
8 & 1.8 & 2.5 & 0.041 \\
9 & 1.5 & 2.4 & 0.041 \\
10 & 1.5 & 2.5 & 0.042 \\
11 & 1.75 & 4 & 0.040 \\
12 & 2 & 5.7 & 0.039 \\
13 & 2 & 6 & 0.039 \\
14 & 2 & 6 & 0.039 \\
\hline
\end{tabular}

Table 3. Average values of the Manning number $n$ estimated using the methodology of Arcement and Schneider (1989).

\begin{tabular}{|l|c|}
\hline \multicolumn{1}{|c|}{ Coastal types } & Manning number $(n)$ \\
\hline Lagoon, fluvial plain & $0.01-0.015$ \\
Mediterranean vegetation & $0.016-0.025$ \\
Farm area & $0.026-0.035$ \\
Discontinuous dune belts (without vegetation) & $0.036-0.040$ \\
Dune belts (Altitude $\geq 3 \mathrm{~m}$ ) & $0.041-0.046$ \\
Rocky coasts (very karstifyed) & $0.047-0.052$ \\
Urban area discontinuous & $0.053-0.058$ \\
Urban area (with buildings very concentrated) & $0.059-0.064$ \\
Mangrooves & $0.065-0.069$ \\
Forests, Pinewood, etc. & $\geq 0.07$ \\
\hline
\end{tabular}

(Manning number), $h_{\mathrm{c}}$ (Altitude of the cliff) and $\alpha$ (emergent slope of the coast) are strictly related to the surface on which the tsunami flooded the coastal area and were directly measured in field. The selected area has been divided into 14 buffers $300 \times 50 \mathrm{~m}$ (Fig. 8). In Table 1 are reported size and weight of the boulders B3, B4, B13 reconstructed from 3D models by using TLS survey techniques (Figs. 7(a, $\mathrm{b}, \mathrm{c})$ ), distance from the coastline and tsunami wave height required to their transport according to the Pignatelli et al. (2009) method. Moreover, we provided a comparison with measurements and calculations performed by using analogical methods for the same boulders in our previous work (Scicchitano et al., 2007).

Volumes calculated in the previous work appear to be overestimated with respect to values estimated by 3D model analyses, probably depending on having approximated the shape of the boulders to a parallelepiped. In fact, the use of TLS underlined that the classic method of boulder measurement tends to overestimate the three main axes and, as consequence, the weight of the boulder (see also Marsico et al., 2009). Since the Pignatelli et al. (2009) hydrodynamic equations are built around the $c$-axis value, this approximation induce an evident overestimation of the minimum wave height able to detach and scatter inland the boulders. Moreover, in the previous works an average value of the density $\left(2.28 \mathrm{ton} / \mathrm{m}^{3}\right)$ was considered for the boulders located in Maddalena peninsula, but new analyses furnished different values ranging between $1.98 \mathrm{ton} / \mathrm{m}^{3}$ and $2.33 \mathrm{ton} / \mathrm{m}^{3}$ also (Table 1).

Unlike the previous work, where the axis dimension of the boulders and the distance of the boulders from the coastline were measured in field by an invar rod mechanical system, in the present work, in this work we estimated the axis dimension of the boulders by analyzing several planar sections extracted from the 3D model (Fig. 7(d)). For example, as regards the boulder $\mathrm{B} 3$, in the previous work $a-, b-, c$ axis we were estimated to be $8 \mathrm{~m}, 5 \mathrm{~m}, 0.7 \mathrm{~m}$, respectively (Table 1). TLS reconstruction furnished values of $5.76 \mathrm{~m}$ for $a$-axis, $4.95 \mathrm{~m}$ for $b$-axis and $1.4 \mathrm{~m}$ for $c$-axis. Starting from these surveyed measures and from the distance of the boulders from the coastline, aiming at defining the flooding inland limit, the applicability of the Pignatelli et al. (2009) equation needs the knowledge of the cliff height $\left(H_{\mathrm{c}}\right)$ and of the mean slope $(\alpha)$ values. The first value was measured for each buffer directly on field and corrected for tide (Table 2); the second one was calculated from a DEM (definition $1 \times 1 \mathrm{~m}$ ) of the area (Table 2). Average values of the $n$ (the Manning number) have been estimated from Arcement and Schneider (1989) (Table 3). In the Maddalena peninsula, two of the distinct coastal types described in Table 3 can be clearly distinguished: very karstifyed rocky coasts, characterized by $n$ ranging between 0.047 and 0.052 (average value $=0.0495$ ), and a pebble sandy berm/soil cover whit shaved vegetation whose $n$ value can be considered similar 
to that of the discontinuous dune belts, characterized by $n$ ranging between 0.036 and 0.040 (average value $=0.038$ ). Considering for each buffer the surface of rocky coasts and soil cover related to their $n$ values, we obtained weighed average values of roughness coefficients $(n)$ from:

$$
n=\left[\left(A_{\mathrm{k}} n_{\mathrm{k}}\right)+\left(A_{\mathrm{d}} n_{\mathrm{d}}\right)\right] /\left(A_{\mathrm{k}}+A_{\mathrm{d}}\right)
$$

with $A_{\mathrm{k}}$ rocky coast surface, $n_{\mathrm{k}}$ manning number for rocky coast $(n=0.0495), A_{d}$ berm/soil cover surface, $n_{\mathrm{d}}$ manning number for berm/soil cover $(n=0.038)$. Obtained values have been reported in Table 2. In the following, we apply the Pignatelli et al. (2009) equation to calculate the maximum inland penetration limits for each buffer in which the area has been divided, considering distinct tsunami heights estimated for the biggest boulders found in Maddalena peninsula.

\section{Discussion}

The 3D model reconstruction of each analyzed boulder highlighted serious discrepancies with measures and estimation performed for the same boulders by Scicchitano et al. (2007) using an invar rod mechanical system. Previous measurements of the $a$-, $b$ - axis of the boulders (Table 1) are overestimated up to $25 \%$ with respect to the values obtained from the 3D models (see boulder B3), whereas the $c$-axis results underestimated up to $50 \%$ (see boulders B3, B13).

The analyses of 3D models allowed us not only to draw the real shape and geometry of the boulders but also to reconstruct the microtopography of the surface of the boulders. Erosion pools and features, flow channels, hole and fractures present on the blocks can be easily related to their geometry and measured. Microtopography analyses helped to depict the pre-transport setting of the considered boulders and the scenario of their transport. In Scicchitano et al. (2007), boulders B3, B4, B13 were all considered into a submerged scenario, but through microtopographical investigation we obtained further constraints that allowed to attribute them to a joint boulders scenario although in a partial submerged environment. Matter of debate could be the type of transport. In a recent paper, Goff et al. (2010) examined the physics of the boulder transport and concluded that the suspension is unrealistic, whereas the entrainment and/or the saltation are more probable. These types of transport were directly surveyed by Mastronuzzi and Sansò (2004) for boulders moved by a four day stormhundred-thousand of waves-occurred in Adriatic Sea on January 2003 or hypothesized by Hall et al. (2006, 2008) and by Hansom et al. (2008) for the terrible storms impacting on the high British cliffs facing on the North Sea. Despite the conclusions reached by Goff et al. (2010), the general features of the boulders, the absence of significant smaller fragments, the presence of a delicate and continuous band of algal rim and of sparse bio-concretions, all together seem to suggest a transport characterised by a single movement, eluding the possibility that boulders could have been rounded by the abrasion on the surf bench. Experimental data indicated that the maximum pressure exerted by an impacting wave is concentrated at the breaking
Table 4. Tsunami wave height and storm generated wave height estimated for the analyzed boulders at Maddalena peninsula, using the Nott (2003) and Pignatelli et al. (2009) models.

\begin{tabular}{|c|c|c|c|c|}
\hline \multirow{2}{*}{ Boulder } & \multicolumn{2}{|c|}{$\begin{array}{c}\text { Nott }(2003) \\
\text { model }\end{array}$} & \multicolumn{2}{c|}{$\begin{array}{c}\text { Pignatelli } \text { et al. } \\
(2009) \text { model }\end{array}$} \\
\cline { 2 - 5 } & $H_{\mathrm{t}}(\mathrm{m})$ & $H_{\mathrm{s}}(\mathrm{m})$ & $H_{\mathrm{t}}(\mathrm{m})$ & $H_{\mathrm{s}}(\mathrm{m})$ \\
\hline B3 & 6.82 & 27.28 & 5.051 & 20.204 \\
B4 & 3.04 & 12.16 & 3.174 & 12.696 \\
B13 & 2.63 & 10.52 & 3.566 & 14.264 \\
\hline
\end{tabular}

wave depth (Rundgren, 1958); broken waves have less energy, directly connected to their height, period and length. Undoubtedly, when a tsunami arrives at the coastline it is already broken; its velocity is dramatically decreasing due to its friction on the bottom and length and period values are also changing. The only effective force on the cliff/sloping coast is exerted by the water hammer effect due to the increasing of the wave height since the impact on the coast and the backwash due to its partial reflection (Goto et al., 2009a). Since the lack of eyewitness, the use of morphological evidence is the only instrument to reconstruct the event and to characterise its features. In Scicchitano et al. (2007), boulders B4 and B13 were interpreted as transported by the same tsunami; dimension of the axis and density of the boulders were processed by using the Nott (2003) model, estimating a minimum tsunami height and storm generated wave height that were compared with the maximum storm generated wave height calculated starting from the dataset of the offshore waves measured by the ondametric buoy of Catania, that is part of the RON (Rete Ondametrica Nazionale $=$ national wave measurement network). In Table 4 values of $H_{\mathrm{t}}$ and $H_{\mathrm{s}}$ calculated for the analysed boulders both with Nott (2003) and Pignatelli et al. (2009) methods are reported.

For the Maddalena peninsula, Scicchitano et al. (2007) estimated a maximum storm generated wave height between $9.31 \mathrm{~m}$ and $9.36 \mathrm{~m}$, by applying the equation of Sunamura and Horikawa (1974) used to calculate the height of a wave at breaking point $\left(H_{\mathrm{b}}\right)$ starting from the height and the period of the same wave measured in deep water $\left(H_{\mathrm{o}}\right)$. Following this method, the wave heights at breaking point were calculated for the most severe storm generated wave registered by the ondametric buoy of Catania since 1989 $\left(H_{\mathrm{o} 1989}=6.2 \mathrm{~m} ; H_{\mathrm{b} 1989}=9.31 \mathrm{~m}\right)$ and for the most severe storm generated wave supposable for the area with a return period of 50 years $\left(H_{\mathrm{o} T 50}=6.24 \mathrm{~m} ; H_{\mathrm{b} T 50}=9.36 \mathrm{~m}\right)$ estimated by applying the Gumbel treatment to available recorded data (Inghilesi et al., 2000) (Fig. 8). $H_{\mathrm{s}}$ values calculated by the Nott (2003) and Pignatelli et al. (2009) methods appear to be in any case higher than these values, confirming the results proposed by Scicchitano et al. (2007) namely, that the boulders were transported inland by tsunami events.

Important indications come also from the analysis of the bathymetry in front of the promontory-about $-5 \mathrm{~m}-$ jointly to the estimation of the bottom slope. A storm wave reaches at breaking point its maximum height, but as soon as it over runs the breaking point it breaks and continuously decreases in height until it approaches the coastline. Exper- 


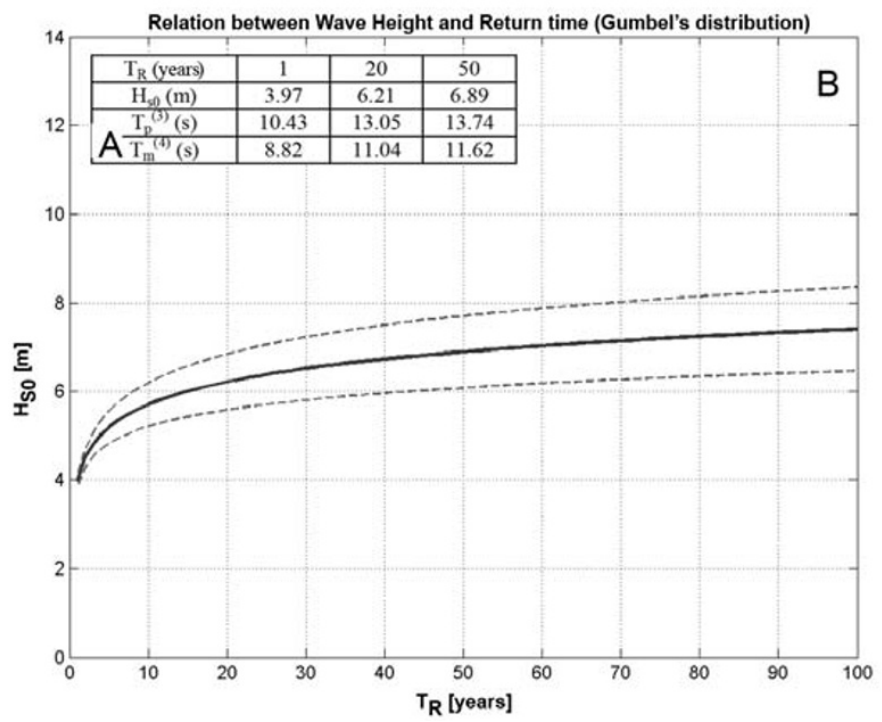

Fig. 8. Diagram showing the relation between wave height and return time (Gumbel's distribution).

Table 5. Inland penetration limit calculated at Maddalena peninsula for boulders B3, B4 and B13.

\begin{tabular}{|c|c|c|c|c|c|c|}
\hline \multirow{2}{*}{$\begin{array}{l}\text { Buffer } \\
\text { number }\end{array}$} & \multirow[t]{2}{*}{$h_{\mathrm{c}}(\mathrm{m})$} & \multirow[t]{2}{*}{$\alpha\left({ }^{\circ}\right)$} & \multirow{2}{*}{$\begin{array}{c}\text { Manning } \\
\text { number }\end{array}$} & \multicolumn{3}{|c|}{ Inland penetration limit (m) } \\
\hline & & & & B3 & B4 & B13 \\
\hline 1 & 1.5 & 4 & 0.042 & 217.85 & 101.02 & 101.95 \\
\hline 2 & 1.8 & 4 & 0.041 & 204.69 & 87.64 & 88.26 \\
\hline 3 & 1.7 & 4 & 0.041 & 211.10 & 92.78 & 93.76 \\
\hline 4 & 1.8 & 4 & 0.041 & $203.95(\min )$ & 87.41 & 87.93 \\
\hline 5 & 1.7 & 3.8 & 0.042 & 205.82 & 91.00 & 91.33 \\
\hline 6 & 1.6 & 2.7 & 0.041 & 216.40 & 97.59 & 98.78 \\
\hline 7 & 1.8 & 2.6 & 0.041 & 206.38 & 88.18 & 89.01 \\
\hline 8 & 1.8 & 2.5 & 0.041 & 206.94 & 88.36 & 89.26 \\
\hline 9 & 1.5 & 2.4 & 0.041 & $223.67(\max )$ & $103.16(\max )$ & $104.78(\max )$ \\
\hline 10 & 1.5 & 2.5 & 0.042 & 216.87 & 10.66 & 101.47 \\
\hline 11 & 1.75 & 4 & 0.040 & 217.98 & 93.50 & 95.56 \\
\hline 12 & 2 & 5.7 & 0.039 & 204.68 & 81.23 (min) & $82.72(\min )$ \\
\hline 13 & 2 & 6 & 0.039 & 205.13 & 81.36 & 82.90 \\
\hline 14 & 2 & 6 & 0.039 & 205.13 & 81.36 & 82.90 \\
\hline & & & & 210.47 (average) & 91.09 (average) & 92.19 (average) \\
\hline
\end{tabular}

imental studies demonstrated that waves break at different distance from the coastline in function of the ratio between impacting wave height $\left(H_{\mathrm{b}}\right)$ and the water depth $\left(W_{\mathrm{d}}\right)$; average values of $0.71-0.78$ have been estimated for this ratio (Keulegan and Patterson, 1940) in case of generic bottom. Experimental data indicate a value of approx $0.44-0.6$ for horizontal bottom or, in case of steeper bottom, of 0.781.03 (Galvin, 1972; Massel, 1997). Therefore, considering that the bottom in front of the Maddalena peninsula is characterised by a mean slope of about $5.7^{\circ}$, it is necessary to apply the first ratio of $0.71-0.78$. A storm wave of about $9.36 \mathrm{~m}$ has the breaking point at about $10-11 \mathrm{~m}$ depth, so at about $50 \mathrm{~m}$ far from the coastline. Considering the breaking distance from the coastline, it is impossible that a similar storm wave (never registered in this area) could occur and be responsible for the detachment and transport of the biggest boulder. Moreover, a normal wave like those registered by RON usually collapse at $W_{\mathrm{d}} 5-6 \mathrm{~m}$, about $20-30 \mathrm{~m}$ far from the coastline. Along this stretch its energy is influ- enced by the roughness of the sea-bottom and arrives dissipated on the coastline, unable to detach from the top of the cliff and scatter $33 \mathrm{~m}$ inland 50 tons heavy boulders. Using the Pignatelli et al. (2009) formula, inland penetration limits were estimated in Maddalena peninsula, for each of the 14 buffer in which the area has been divided, using B3, B4 and B13 as reference boulders (Table 5).

Boulder B3 represents the biggest boulder located in Maddalena peninsula. Using the Pignatelli et al. (2009) method, a minimum tsunami height of $5.051 \mathrm{~m}$ (Table 4) is required to detach the boulder from the cliff top in a JB scenario partially submerged, as evidenced by the presence of the algal rim, and transport it inland. Considering this value, the inland penetration limit has been calculated for each buffer (Table 5) resulting in a max value of $223.67 \mathrm{~m}$, a minimum value of $203.95 \mathrm{~m}$ and an average value of $210.47 \mathrm{~m}$. Estimation for boulder B4 (Table 5) furnished a $H_{\mathrm{T}}$ value a little bit lower with respect to that assessed for the boulder B3, reaching an height of $3.174 \mathrm{~m}$, 


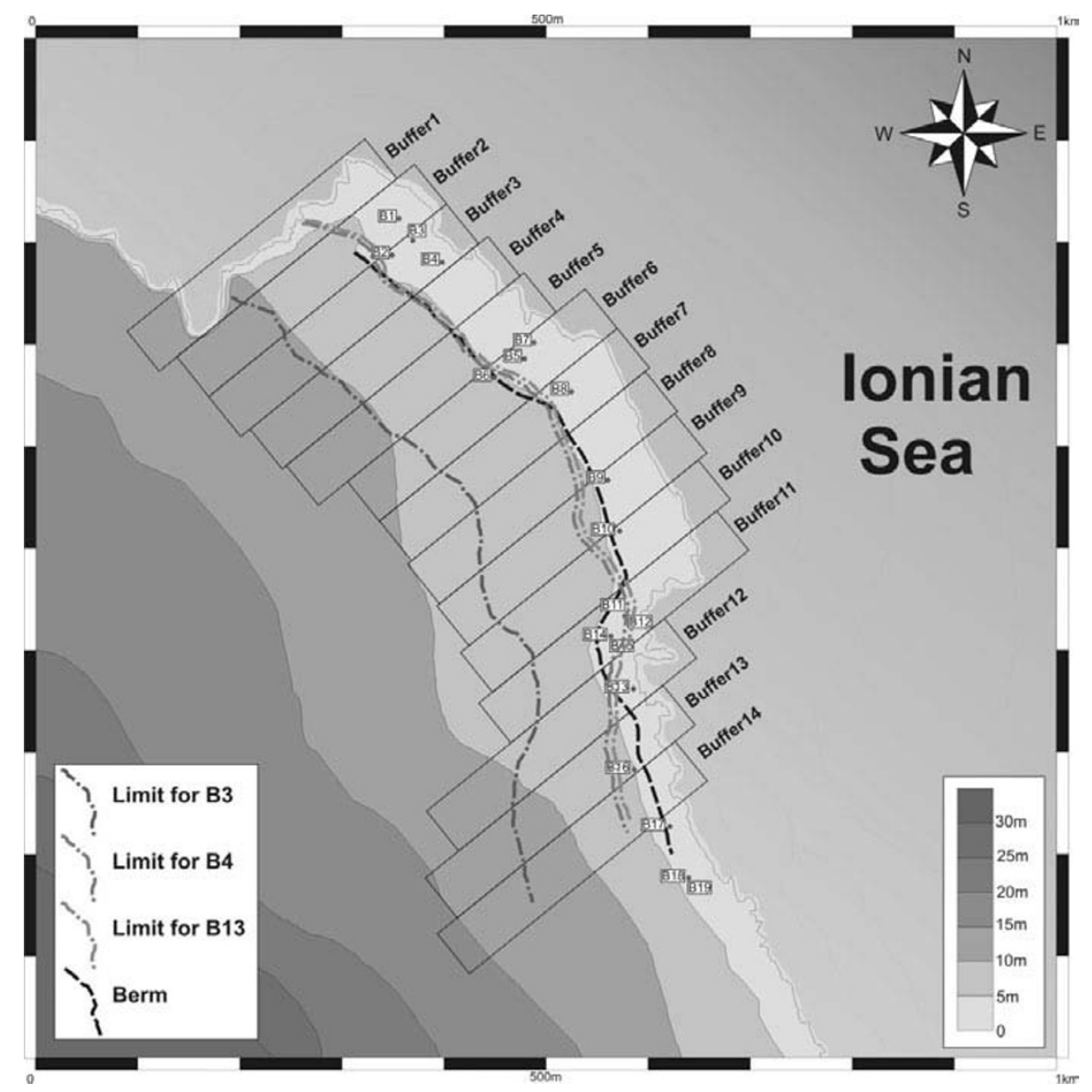

Fig. 9. Inland penetration limits evaluated at Maddalena peninsula using the Pignatelli et al. (2009) method (see Fig. 1(c) for location).

inland penetration limits ranging between a minimum value of $81.23 \mathrm{~m}$ and a maximum value of $103.16 \mathrm{~m}$ with an average value of $91.09 \mathrm{~m}$. For the boulder B13 (Table 5), a $H_{\mathrm{T}}$ of $3.566 \mathrm{~m}$ has been estimated; consequently, the minimum inland penetration limit is about $82.72 \mathrm{~m}$, the maximum is about $104.78 \mathrm{~m}$, the average value $92.19 \mathrm{~m}$. Average inland penetration limit estimated for B4 and B13 appear to be in good agreement, suggesting that the two boulders could have been transported during the same event. This is confirmed by radiocarbon age determination performed by Scicchitano et al. (2007) on these boulders, yielding an age of $465 \pm 37$ age (BP) for boulder B4 and $465 \pm 35$ age (BP) for boulder B13 (not calibrated), that allowed to refer their accumulation to the December 28, 1908 tsunami.

As regards the inland penetration limits along the Maddalena peninsula, they have been reported in Fig. 9: it is worth to note the good correspondence between the limits calculated for boulders B4 and B13 and the berm located in the peninsula, from buffer 1 to buffer 10 . In buffer 11 the two limits appear to stay closer to the coastline than the berm, but it must be considered that this buffer is not properly orientated with respect to the shoreline. In buffers 12 , 13 and 14 the limit of B4 and B13 is located at a distance of about 20-30 $\mathrm{m}$ from the berm, since the slope is characterized by two steps and it is not regular as in the other buffers. In general, we can affirm that the good agreement between the limits calculated for B4 and B13 and the berm surveyed in the Maddalena peninsula suggests that the same event
(1908 tsunami) has been responsible for their deposition. A different conclusion must be drawn for boulder B3; unfortunately it was not possible to estimate the age of the event responsible for the deposition of this boulder, because it does not show marine encrustation useful to perform radiocarbon age determination. Two scenario can be considered: i) the boulder B3 has been deposited by an event occurred before 1908; ii) the boulder has been deposited by the 1908 event. The first hypothesis seems more reliable considering that in the area located between the berm and the B3 limit several small boulder weighing up to $30 \mathrm{~kg}$, totally encrusted of marine organisms, were found. This suggests that another more extreme event could have occurred before the deposition of the berm but we did not find indication about its age. Another explanation for the different extension of the inland flooding calculated for B3 could be find in the local variability of the morphological features of the Maddalena peninsula coastline. Boulder B3 is placed in a sector of the peninsula where the more articulated coastline and sea bottom could have caused a sensible increasing of the wave responsible for its transport. Besides, it is really very difficult to imagine a regular coastline uniformly conditioning the wave progression, as indicate in recent papers (Mastronuzzi et al., 2006; Goto et al., 2009a; Pignatelli et al., 2009) and underlined by Imamura in Benner et al. (2010). Moreover, the non-correspondence of the assessed inundation limit to the position of the berm could be explained considering that the micro-topography of the surf bench is not yet well rep- 
resented by scheduled Manning's number. The area of the boulder B3 has been considered uniform with respect to all the remaining surface: in effect, it is locally characterised by a "phantom" topography that cannot be recognised by the human eyes but only by a digital survey. Most likely, the presence of extended partially destroyed quarry and karstic pools should increase the real Manning's number respect to the weighed averaged used for buffer 2 up to the value 0.05 . The need of surveys devoted to obtain the real value of this parameter is evident as suggested by Pignatelli et al. (2010).

\section{Conclusions}

The Maddalena peninsula preserves the evidence of the recent impact of the disastrous tsunami occurred on December 28, 1908. Its coastal area is characterised by the presence of a boulder field with blocks weighting up to 50 tons whose pre-transport scenario seems to have been the "joint bounded". Generally, the boulders come from the adlittoral/infralittoral area and their deposit is associated to those of stripping soil and of a gravel/sandy berm. A detailed TLS/DGPS surveys has been performed in order to obtain more detailed data that can describe, morphologically and topographically, the three biggest boulders and the berm shaped by the impact of the waves. New data indicate a general previous overestimation - up to the $50 \%$ - of the dimensions, volumes and weights of the surveyed boulders. Surveyed data have been computed in different steps in order to verify the conclusions of previous works and to improve the knowledge on the effect of the 1908 tsunami:

- the application of the most recent equations using the size and weight parameters of three boulders for the evaluation of the possible tsunami height responsible for their deposition suggested that two boulders have been moved by waves characterized by the same height while the third one seems to have been moved by a biggest wave;

- the digital analysis of the local emerged and submerged topography compared to the available recorded and statistical data concerning the local wave climate allowed us to exclude the deposition of the boulders due to the impact of normal storm generated waves;

- the use of the inundation formulas permitted to evaluate the minimum inland flooding of the events responsible for the boulders scattering, transport and deposition: in general a good agreement has been recognised since the value are included in a range of $\pm 10 \mathrm{~m}$, that is a reasonable value considering the variability of the topography and, as consequence, the differential decreasing of the inland running wave;

- the use of DGPS permitted to verify that these estimated values correspond to the measured position of the inland limit of the strip soil and of the pebble/sandy berm.

- The use of TLS and DGPS sensibly improved the accuracy of field measurements allowing a better estimation of the tsunami wave height and inland penetration limit.

In the case of the Maddalena peninsula, the results obtained elaborating the digitally surveyed data fit reasonably well, confirming the conclusions of our previous work that showed the evidence of the impact of the December 28, 1908 tsunami wave. However, some improvements are required in order to obtain experimental "in situ" real Manning's number that can optimise the application of the flooding assessment formulas.

Acknowledgments. This research has been financially supported by INGV-DPC Project S1 2007/09 “Analysis of the seismic potential in Italy for the evaluation of the seismic hazard" (Nat. Resp.: S. Barba, C. Doglioni; Unit 6.03 Resp.: G. Mastronuzzi), by Research Project of Bari University 2009 "Modellizzazione e valutazione del rischio costiero da eventi parossistici" (Resp. Prof. G. Mastronuzzi) and by University of Catania funds (Resp. C. Monaco). Many thanks are due to C. Marziano for the important suggestions supported. We are grateful to the Marine Protected Area of Plemmirio for the aerial views they supplied us. The authors sincerely thank the two anonymous reviewers for helpful corrections and valuable comments on the manuscript.

\section{References}

Arcement, G. and V. Schneider, Guide for selecting Manning's roughness coefficients for natural channels and flood plains, U.S. Geol. Surv. Water Supply Pap., 2339, 1989.

Argnani, A. and C. Bonazzi, Malta Escarpment fault zone offshore eastern Sicily: Pliocene-Quaternary tectonic evolution based on new multichannel seismic data, Tectonics, 24, TC 4009, doi:10.1029/2004TC001656, 2005.

Asal, F. F. F., Airborne remote sensing for landscape modelling, $\mathrm{PhD}$ thesis, 317 pp., The University of Nottingham, UK, 2003.

Azzaro, R. and S. Barbano, Analysis of the seismicity of southeastern Sicily: a proposed tectonic interpretation, Annali di Geofisica, 43, 171188, 2000.

Baratta, M., La catastrofe sismica calabro-messinese (28 Dicembre 1908), Relazione alla Soc. Geogr. Ital., 1910.

Barbano, M. S., C. Pirrotta, and F. Gerardi, Large boulders along the southeastern Ionian coast of Sicily: Storm or tsunami deposits?, Mar. Geol., doi:10.1016/j.margeo.2010.05.005, 2010.

Barbano, S., The Val di Noto earthquake of January 11, 1693, in Atlas of Isoseismal Maps of Italian Earthquake, edited by D. Postpischl, PGFCNR, Quaderno Ricerche Scientifiche 114 (2A), 48-49, 1985.

Barbano, S. and M. Cosentino, Il terremoto siciliano dell'11 Gennaio 1693, Rend. Soc. Geol. Ital., 4(5), 517-522, 1981.

Benner, R., T. Browne, H. Brückner, D. Kelletat, and A. Scheffers, Boulder transport by waves: Progress in physical modelling, Zeitschrift für Geomorphologie, 54(3), 127-146, 2010.

Bianca, M., C. Monaco, L. Tortorici, and L. Cernobori, Quaternary normal faulting in southeastern Sicily (Italy): A seismic source for the 1693 large earthquake, Geophys. J. Int., 139, 370-394, 1999.

Boschi, E., G. Ferrari, P. Gasperini, E. Guidoboni, G. Smiraglio, and G. Valensise, Catalogo dei forti terremoti in Italia dal 461 a.c. al 1980, Istituto Nazionale di Geofisica, S.G.A., Roma, 1995.

Bourgeois, J. and B. MacInnes, Tsunami boulder transport and other dramatic effects of the 15 November 2006 central Kuril Islands tsunami on the island of Matua, Zeitschrift fuer Geomorphologie, 54(3), 175-195, 2010.

Bryant, E. A., Tsunami, The Underrated Hazard, 320 pp., Cambridge University Press, Cambridge, UK, 2001.

Carbone, S., M. Cosentino, M. Grasso, F. Lentini, G. Lombardo, and G. Patanè, Elementi per una prima valutazione dei caratteri sismotettonici dell'Avampaese Ibleo (Sicilia sud-orientale), Mem. Soc. Geol. It., 24, 507-520, 1982.

Chow, V. T., Open-Channel Hydraulics, McGraw-Hill, New York, 1973.

De Martini, P. M., M. S. Barbano, A. Smedile, F. Gerardi, D. Pantosti, P. Del Carlo, and C. Pirrotta, A unique 4000 year long geological record of multiple tsunami inundations in the Augusta Bay (eastern Sicily, Italy), Mar. Geol., 276(1-4), 42-57, 2010.

Galvin Jr., C. J., Wave breaking in shallow water, in Waves on Beaches and Resulting Sediment Transport, edited by R. E. Meyer, pp. 413-456, Academic Press, New York, 1972.

Ghisetti, F., Fault parameters in the Messina Strait (southern Italy) and relations with the seismogenic source, Tectonophysics, 210, 117-133, 1992. 
Goff, J., R. Weiss, C. Courtney, and D. Dominey-Howes, Testing the hypothesis for tsunami boulder deposition from suspension, Mar. Geol., 277(1-4), 73-77, 2010.

Goto, K., S. A. Chavanich, F. Imamura, P. Kunthasap, T. Matsui, K. Minoura, D. Sugawara, and H. Yanagisawa, Distribution, origin and transport process of boulders deposited by the 2004 Indian Ocean tsunami at Pakarang Cape, Thailand, Sediment. Geol., 202, 821-837, 2007.

Goto, K., K. Okada, and F. Imamura, Importance of the initial waveform and coastal profile for the tsunami transport of boulders, Polish J. Environ. Stud., 18, 53-61, 2009a.

Goto, K., K. Okada, and F. Imamura, Characteristics and hydrodynamics of boulders transported by storm wave at Kudaka Island, Japan, Mar. Geol., 262, 14-24, 2009b.

Goto, K., T. Kawana, and F. Imamura, Historical and geological evidence of boulders deposited by tsunamis, southern Ryukyu Island, Japan, Earth-Sci. Rev., 102, 77-99, 2010a.

Goto, K., K. Miyagi, H. Kawamata, and F. Imamura, Discrimination of boulders deposited by tsunamis and storm waves at Ishigaki Island, Japan, Mar. Geol., 269, 34-45, 2010 b.

Grasso, M. and F. Lentini, Sedimentary and tectonic evolution of the eastern Hyblean Plateau (southeast Sicily) during Late Cretaceous to Quaternary times, Palaeo. Palaeo. Palaeo., 39, 261-280, 1982.

Hall, A. M., J. D. Hansom, D. M. Williams, and J. Jarvis, Distribution, geomorphology and lithofacies of cliff-top storm deposits: Examples from the high-energy coasts of Scotland and Ireland, Mar. Geol., 232, 131-155, 2006.

Hall, A. M., J. D. Hansom, and J. Jarvis, Patterns and rates of erosion produced by high energy wave processes on hard rock headlands: The Grind of the Navir, Shetland, Scotland, Mar. Geol., 248(1-2), 28-46, 2008.

Hansom, J. D., N. D. P. Barltrop, and A. M. Hall, Modelling the processes of cliff-top erosion and deposition under extreme storm waves, Mar. Geol., 253, 36-50, 2008.

Hills, J. G. and C. L. Mader, Tsunami produced by the impacts of the small asteroids, Ann. N. Y. Accad. Sci., 822, 381-394, 1997.

Hirn, A., R. Nicolich, J. Gallart, M. Laigle, L. Cernobori, and ETNASEIS Scientific Group, Roots of Etna volcano in faults of great earthquakes, Earth Planet. Sci. Lett., 148, 171-191, 1997.

Imamura, F., K. Goto, and S. Ohkubo, A numerical model for the transport of a boulder by tsunami, J. Geophys. Res., 113, CO1008, doi:10.1029/2007JC004170, 2008.

Inghilesi, R., S. Corsini, F. Guiducci, and A. Arseni, Statistical analysis of extreme waves on the Italian coasts from 1989 to 1999 , Boll. Geofis. Teor. Appl., 41(3-4), 315-337, 2000.

Jacques, E., C. Monaco, P. Tapponnier, L. Tortorici, and T. Winter, Faulting and earthquake triggering during the 1783 Calabria seismic sequence, Geophys. J. Int., 147, 499-516, 2001.

Kelletat, D., Comments to Dawson, A. G. and Stewart, I. (2007)—Tsunami deposits in the geological record, Sediment. Geol., 211, 87-91, 2008.

Kelletat, D., S. Scheffers, and A. Scheffers, Learning from the SE-Asian tsunami: Examples from Thailand's west coast, Geograph. Rundschau Int., 1, 4-9, Braunschweig, 2006.

Kelletat, D., A. Scheffers, and S. Scheffers, Field signatures of the SE336 Asian mega-tsunami along the west coast of Thailand compared to Holocene paleo-tsunami from the Atlantic region, Pure Appl. Geophys., 164(2/3), 413-431, 2007.

Keulegan, G. H. and G. W. Patterson, Mathematical theory of irrotational translation waves, J. Res. Natl. Bur. Stand., 24, 47-101, 1940.

Lavigne, F., R. Paris, P. Wassmer, C. Gomez, D. Brunstein, D. Grancher, F. Vautier, J. Sartohadi, A. Setiawan, T. G. Syahnan, B. W. Fachrizal, D. Mardiatno, A. Widagdo, R. Cahyadi, N. Lespinasse, and L. Mahieu, Learning from a Major Disaster (Banda Aceh, December 26th, 2009): A Methodology to Calibrate Simulation Codes for Tsunami Inundation Models, Zeitschrift für Geomorphologie N.F., Suppl.-Bd., 146, 253-265, 2006.

Leica Geosystems, HDS Scanning and Cyclone Training Manual, 540 pp., Leica Geosystems HDS San Ramon California, 2004.

Lombardo, G., The Catania earthquake of February 4, 1169, in Atlas of Isoseismal Maps of Italian Earthquake, edited by D. Postpischl, PGFCNR, Quaderno Ricerche Scientifiche 114 (2A), 12-13, 1985.

Maouche, S., C. Morhange, and M. Meghraoui, Large boulder accumulation on the Algerian coast evidence tsunami events in the western Mediterranean, Mar. Geol., 262, 96-104, 2009.

Marsico, A., C. Pignatelli, A. Piscitelli, G. Mastronuzzi, and L. Pennetta, Ricostruzione Differential e di blocchi accumulati da eventi estremi in Italia meridionale, Atti 13 a Conferenza Nazionale ASITA, 1-4 dicembre
2009, 1377-1385, 2009

Marziano, C., Rinvenimenti Paleontologici nell'area del Plemmirio e delle Saline di Siracusa, Atti e Memorie dell'Ente Fauna Siciliana, Vol. IX, 2004.

Massel, S. R., Prediction of the largest surface wave height in water of constant depth, in Recent Advances in Marine Science and Technology 96, edited by N. Saxena, pp. 141-151, PACON International, Honolulu, USA, 1997.

Mastronuzzi, G., Tsunami in Mediterranean sea, The Egyptian J. Environ. Change, 2(1), 1-9, 2010.

Mastronuzzi, G. and P. Sansò, Boulders transport by catastrophic waves along the Ionian coast of Apulia (Southern Italy), Mar. Geol., 170, 93 103, 2000.

Mastronuzzi, G. and P. Sansò, Large boulder accumulations by extreme waves along the Adriatic coast of southern Apulia (Italy), Quatern. Int., 120, 173-184, 2004.

Mastronuzzi, G., C. Pignatelli, and P. Sansò, Boulder fields: A valuable morphological indicator of paleotsunami in the mediterranean sea, Zeitschrift für Geomorphologie, NF Suppl.-Bd., 146, 173-194, 2006.

Mastronuzzi, G., C. Pignatelli, P. Sansò, and G. Selleri, Boulder accumulations produced by the 20th February 1743 tsunami along the coast of southeastern Salento (Apulia region, Italy), Mar. Geol., 242(1), 191205, 2007.

Monaco, C. and L. Tortorici, Active faulting in the Calabrian arc and eastern Sicily, J. Geodyn., 29, 407-424, 2000.

Noormets, R., E. A. Felton, and K. A. W. Crook, Sedimentology of rocky shorelines: 2. Shoreline megaclasts on the north shore of Oahu, Hawaii-origins and history, Sediment. Geol., 150, 31-45, 2002.

Noormets, R., K. A. W. Crook, and E. A. Felton, Sedimentology of rocky shorelines: 3. Hydrodynamics of megaclast emplacement and transport on a shore platform, Oahu, Hawaii, Sediment. Geol., 172, 41-65, 2004.

Nott, J., Extremely high-energy wave deposits inside the Great Barrier reef, Australia: Determining the cause-tsunami or tropical cyclone, Mar. Geol., 141, 193-207, 1997.

Nott, J., Waves, coastal boulders and the importance of the pre-transport setting, Earth Planet. Sci. Lett., 210, 269-276, 2003.

Paris, R., F. Lavigne, P. Wassmer, and J. Sartohadi, Coastal sedimentation associated with the December 26, 2004 in Lhok Nga, west Banda Aceh (Sumatra, Indonesia), Mar. Geol., 238, 93-106, 2007.

Paris, R., P. Wassmer, J. Sartohadi, F. Lavigne, B. Barthomeuf, E. Desgages, D. Grancher, P. Baumert, F. Vaultier, D. Brunstein, and C. Gomez, Tsunamis as geomorphic crisis: lessons from the December 26, 2004 tsunami in Lhok Nga, west Banda Aceh (Sumatra, Indonesia), Geomorphology, 104(1-2), 59-72, 2009.

Paris, R., J. Fournier, E. Poizot, S. Etienne, J. Morin, F. Lavigne, and P. Wassmer, Boulder and fine sediment transport and deposition by the 2004 tsunami in Lhok Nga (western Banda Aceh, Sumatra, Indonesia): A coupled offshore-onshore model, Mar. Geol., 268(1-4), 43-54, 2010.

Piatanesi, A. and S. Tinti, A revision of the eastern Sicily earthquake and tsunami, J. Geophys. Res., 103, 2749-2758, 1998.

Pignatelli, C., P. Sansò, and G. Mastronuzzi, Evaluation of tsunami flooding using geomorphologic evidence, Mar. Geol., 260(1), 6-18, 2009.

Pignatelli, C., A. Piscitelli, B. Damato, and G. Mastronuzzi, Estimation of the value of Manning's coefficient using Terrestrial Laser Scanner techniques for the assessment of extreme waves flooding, Zeitschrift für Geomorphologie, 54(3), 317-336, 2010.

Postpischl, D., Catalogo dei terremoti italiani dall'anno 1000 al 1980, CNR, P.F. Geodinamica, Graficoop, Bologna, 239 pp., 1985.

Regnauld, H., J. Oszwald, O. Planchon, C. Pignatelli, A. Piscitelli, G. Mastronuzzi, and A. Audevard, Polygenetic (tsunami and storm) deposits? A case study from Ushant Island, western France, Zeitschrift für Geomorphologie NF., 54, Suppl. 3, 197-217, 2010.

Richmond, B. M., B. E. Jaffe, G. Gelfenbaum, and R. A. Morton, Geologic impacts of the 2004 Indian Ocean Tsunami on Indonesia, Sri Lanka, and the Maldives, Zeitschrift für Geomorphologie N.F. Suppl., 146, 235251, 2006.

Rundgren, L., Water wave forces, Royal Institute of Technology, Division of Hydraulics, Stockholm, Sweden, n. 54, 1958.

Sartori, R., M. L. Colalongo, G. Gabbianelli, C. Bonazzi, S. Carbone, P. V. Curzi, D. Evangelisti, M. Grasso, F. Lentini, S. Rossi, and L. Selli, Note stratigrafiche e tettoniche sul rise di Messina (Ionio nord-occidentale), Giornale di Geologia, 53, 49-64, 1991.

Scandone, P., E. Patacca, R. Radoicic, W. B. F. Ryan, M. B. Cita, M. Rawson, H. Chezar, E. Miller, J. Mckenzie, and S. Rossi, Mesozoic and Cenozoic rocks from Malta Escarpment (Central Mediterranean), A.A.P.G. Bull., 65, 1299-1319, 1981. 
Scheffers, A., Paleotsunami Evidences of tsunami from Boulder deposits on Aruba, Curaçao, and Bonaire, Sci. Tsunami Haz., 20(1), 26-37, 2002.

Scheffers, A., Tsunami imprints on the Leeward Netherlands Antilles (Aruba, Curaçao and Bonaire) and their relation to other coastal problems, Quatern. Int., 120(1), 163-172, 2004.

Scheffers, A., Sedimentary impacts of Holocene tsunami events from the intra Americas seas and southern Europe-A review, ZGeomorph N.F., Suppl. Bd., 146, 7-37, 2006.

Scheffers, A., Tsunami Boulder Deposits, in Tsunamiites, edited by T. Shiki, Y. Tsuji, T. Yamazaki, and K. Minoura, Feature and Implications, 299-318, Elsevier, 2008.

Scheffers, A. and S. Scheffers, Documentation of the impact of hurricane Ivan on the coastline of Bonaire (Netherlands Antilles), J. Coast. Res., 22(6), 1437-1450, 2006.

Scheffers, A. and D. Kelletat, Tsunami relics in the coastal landscape west of Lisbon, Portugal, Sci. Tsunami Haz., 23(1), 3-16, 2005.

Scicchitano, G., C. Monaco, and L. Tortorici, Large boulder deposits by tsunamis along the Ionian coast of south-eastern Sicily (Italy), Mar. Geol., 238, 75-91, 2007.

Scicchitano, G., F. Antonioli, E. F. Castagnino Berlinghieri, A. Dutton, and $\mathrm{C}$. Monaco, Submerged archaeological sites along the Ionian coast of south-eastern Sicily (Italy) and implications with the relative sea level change during the late Holocene, Quatern. Res., 70, 26-39, 2008.

Scicchitano, G., B. Costa, A. Di Stefano, S. G. Longhitano, and C. Monaco, Tsunami and storm deposits preserved within a ria-type rocky coastal setting (Siracusa, SE Sicily), Zeitschrift fur Geomorphologie, 54, Suppl. 3, 51-77, 2010.

Slob, S. and R. Hack, 3D terrestrial laser scanning as a new field measurement and monitoring technique, in Engineering Geology for Infrastructure Planning in Europe: A European Perspective, edited by R. Hack, R. Azzam, and R. Charlier, Lecture Notes in Earth Sciences, Vol. 104, publ. Springer-Verlag Heidelberg, ISBN: 3-540-21075X, doi:10.1007/b93922, pp. 800, 2004.

Smedile, A., P. M. De Martini, D. Pantosti, L. Bellucci, P. Del Carlo, L. Gasperini, C. Pirrotta, A. Polonia, and E. Boschi, Possible tsunami signatures from an integrated study in the Augusta Bay offshore, Mar. Geol., 281(2011), 1-13, 2011.

Srinivasalu, S., N. Thangadurai, A. D. Switzer, V. Ram Mohan, and T. Ayyamperumal, Erosion and sedimentation in Kalpakkam (N Tamil Nadu, India) from the 26th December 2004 Tsunami, Mar. Geol., 240(1-4), 65-75, 2007.

Sunamura, T. and K. Horikawa, Two dimensional beach transformation due to waves, Proceedings 14th Coastal Engineering Conference, American Society of Civilian Engineerings, 920-938, 1974.

Szczuciski, W., P. Niedzielski, G. Rachlewicz, T. Sobczyski, A. Ziola, A. Kowalski, S. Lorenc, and J. Siepak, Contamination of tsunami sediments in a coastal zone inundated by the 26 December 2004 tsunami in Thailand, Environ. Geol., 49(2), (month and year of the edition), 321331, 2005.

Tinti, S. and A. Armigliato, The use of scenarios to evaluate the tsunami impact in southern Italy, Mar. Geol., 199, 221-243, 2003.

Tinti, S., A. Maramai, and L. Graziani, The new catalogue of Italian tsunamis, Nat. Haz., 33, 439-465, 2004.

Tinti, S., A. Maramai, and L. Graziani, The Italian Tsunami Catalogue (ITC), Version available on-line at http://www.ingv.it/servizi-erisorse/BD/catalogo-tsunami/catalogo-degli-tsunami-italiani, 2007.

Umitsu, M., C. Tanavud, and B. Patanakanog, Effects of landforms on tsunami flow in the plains of Banda Aceh, Indonesia, and Nam Khem, Thailand, Mar. Geol., 242(1-3), 141-153, 2007.

Valensise, G. and D. Pantosti, A 125 Kyr long geological record of seismic source repeatability: the Messina Straits (southern Italy) and the 1908 earthquake (Ms 71/2), Terra Nova, 4, 472-483, 1992.

Williams, D. M. and A. M. Hall, Cliff-top megaclast deposits of Ireland, a record of extreme waves in the North Atlantic-storms or tsunamis?, Mar. Geol., 206, 101-117, 2004.

G. Scicchitano (e-mail: gianfrancoscicc@hotmail.com), C. Pignatelli, C. R. Spampinato, A. Piscitelli, M. Milella, C. Monaco, and G. Mastronuzzi 